\title{
Covering lleal Loop without Ostomy: A New Approach to Bring Down the Enterostomy-Related Morbidity
}

\author{
Kathiresan Karunakaran ${ }^{1}$ Palanisamy Jayakumar ${ }^{2, \oplus}$ Dheivendiran Maruthupandian ${ }^{2}$ \\ ${ }^{1}$ Department of General Surgery, Sivagangai Medical College, \\ Sivagangai, Tamil Nadu, India \\ ${ }^{2}$ Department of Paediatric Surgery, Madurai Medical College, \\ Madurai, Tamil Nadu, India

\begin{abstract}
Address for correspondence Palanisamy Jayakumar, MBBS, MS, MCh, Department of Paediatric Surgery, Madurai Medical College and Government Rajaji Hospital, Madurai, Tamil Nadu 625020, India (e-mail: drjayakumar1999@gmail.com).
\end{abstract}

Int J Recent Surg Med Sci 2021;7:77-79.

\author{
Abstract \\ Keywords \\ - Colorectal Surgery \\ - Covering Loop \\ - lleostomy \\ Modification
}

lleostomy is a commonly performed procedure for colon surgeries and the following emergency small or large bowel resection and anastomosis. We proposed a successful new technique of covering ileal loop without opening it, to decrease the stoma and reversal-related complications.

\section{Introduction}

Loop ileostomy or colostomy is a commonly performed procedure for colorectal anastomosis, ileocolic anastomosis, and ileoileal anastomosis, whenever needed. Morbidity associated with enterostomies, although not very common, still exists, which includes dehydration, electrolyte disturbances, receding loop, skin excoriation, and wound infection. ${ }^{1-3}$ We performed a few modifications in the loop ileostomy and ghost ileostomy, which will avoid or reduce morbidities associated with loop enterostomies.

\section{Technique to Bring out the lleal Loop}

In temporary loop enterostomies, to bring the stoma outside, we poke the mesentery in between vessels, near the bowel side, and insert a Ryle's tube or feeding tube, in order to make a loop for hold. Tube loop is then brought out through a well-made split rent in the lateral part of rectus, steady traction is also given with clockwise or anticlockwise rotation, which brings out enough loop of bowel for enterostomy ( - Fig. 1A, B). Tube holding the loop of bowel is left in situ, outside the abdominal wall, for a week or two to avoid receding of the loop or to pull the bowel loop when it is receding.

published online June 16, 2021
DOI https://doi.org/

$10.1055 / \mathrm{s}-0041-1731129$ ISSN 2455-7420

\section{Technique to Avoid Stoma-Related Complications}

In contrast to routine enterostomy, bowel loop is not opened (ostomy not done) here ( - Fig. 2A, B). Only normal saline dressing was done till loop reversal.

We can appreciate bowel movement in the loop kept outside during the recovery. Bowel is insensitive to pain, so we can open it in the ward or procedure room whenever we suspect an anastomotic leak.

After a week or two, bowel loop can be reversed into the abdominal cavity, with closure of the split rectus sheath and skin under local anesthesia.

This procedure of covering loop without enterostomy will reduce the chances of infection at ostomy site, leak during reversal of ostomy, and the need for an extra laparotomy in difficult ostomy reversal cases.

\section{Our Experience}

Since 2014, we have done 15 covering loops, and all the cases were open cases done in emergency (-Table $\mathbf{1}$ ). We had opened the loop for one patient due to anastomotic leak who survived. We usually take down the loop by the seventh day 


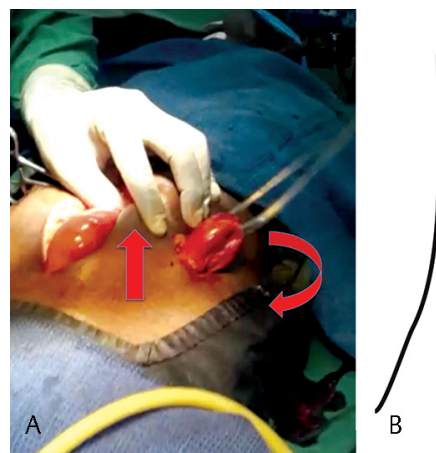

Fig. 1 (A, B) Arrows showing upward steady traction and rotatory movement with the loop of a tube for covering loop creation.
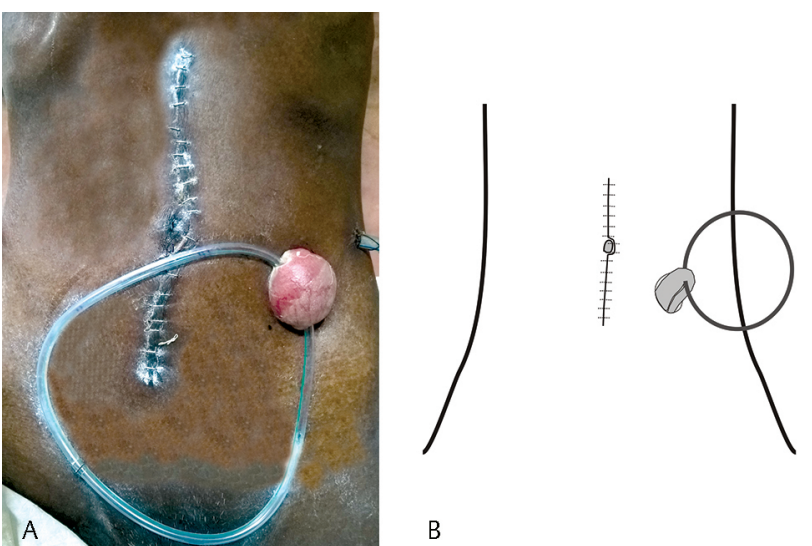

Fig. 2 (A, B) Covering ileal loop without ostomy on seventh postoperative day.

Table 1 Diagnosis, demographics, reversal type, complications and outcome of covering loop patients

\begin{tabular}{|c|c|c|c|c|c|c|c|}
\hline $\begin{array}{l}\text { Serial } \\
\text { number }\end{array}$ & Final diagnosis & $\begin{array}{l}\text { Procedure } \\
\text { done }\end{array}$ & Age & Sex & $\begin{array}{l}\text { Early or delayed } \\
\text { reversal of ileostomy }\end{array}$ & $\begin{array}{l}\text { Complication of } \\
\text { loop reversal }\end{array}$ & $\begin{array}{l}\text { Outcome of the } \\
\text { patient at the end of } \\
\text { minimum } 3 \text { months }\end{array}$ \\
\hline 1. & Mesenteric ischemia & RHC/ITA & 59 & $M$ & Early & None & Live \\
\hline 2. & $\begin{array}{l}\text { Carcinoma cecum } \\
\text { and ascending colon }\end{array}$ & RHC/ITA & 66 & $\mathrm{~F}$ & Early & None & Live \\
\hline 3. & $\begin{array}{l}\text { Carcinoma ascend- } \\
\text { ing colon }\end{array}$ & RHC/ITA & 61 & M & Early & None & Live \\
\hline 4. & Mesenteric ischemia & IR/EEA & 49 & $M$ & Early & None & Live \\
\hline 5. & $\begin{array}{l}\text { Multiple enteric } \\
\text { perforation terminal } \\
\text { ileum }\end{array}$ & IR/EEA & 40 & $\mathrm{~F}$ & Early & None & Live \\
\hline 6. & $\begin{array}{l}\text { Ileocecal } \\
\text { tuberculosis }\end{array}$ & RHC/ITA & 52 & $\mathrm{~F}$ & Late & None & Live \\
\hline 7. & $\begin{array}{l}\text { Perforated carci- } \\
\text { noma cecum }\end{array}$ & RHC/ITA & 61 & M & Late & None & Live \\
\hline 8. & $\begin{array}{l}\text { Ileocecal } \\
\text { tuberculosis }\end{array}$ & RHC/ITA & 66 & $\mathrm{~F}$ & Late & Difficult Reversal & Live \\
\hline 9. & $\begin{array}{l}\text { Mesenteric venous } \\
\text { thrombosis }\end{array}$ & IR/EEA & 70 & $\mathrm{M}$ & Early & $\begin{array}{l}\text { Leak on eighth } \\
\text { postoperative day }\end{array}$ & $\begin{array}{l}\text { Died due to comorbid } \\
\text { tuberculosis and cachexia }\end{array}$ \\
\hline 10. & Cecal volvulus & RHC/ITA & 35 & $\mathrm{~F}$ & Early & None & Live \\
\hline 11. & $\begin{array}{l}\text { Stab injury trans- } \\
\text { verse colon }\end{array}$ & LR/EEA & 53 & $\mathrm{M}$ & Early & None & Live \\
\hline 12. & $\begin{array}{l}\text { Obstructed splenic } \\
\text { Flexure growth } \\
\text { with impending } \\
\text { perforation }\end{array}$ & LHC/CSA & 67 & $\mathrm{~F}$ & Early & None & Live \\
\hline 13. & Sigmoid volvulus & $\mathrm{R} / \mathrm{CRA}$ & 72 & $\mathrm{M}$ & Late & None & Live \\
\hline 14. & Sigmoid volvulus & $\mathrm{R} / \mathrm{CRA}$ & 58 & $F$ & $\begin{array}{l}\text { Stoma created due to } \\
\text { anastomotic leak. Late } \\
\text { reversal after } 3 \text { months } \\
\text { done with ileoileal } \\
\text { anastomosis. }\end{array}$ & None & Live \\
\hline 15. & $\begin{array}{l}\text { Sigmoid diverticular } \\
\text { perforation }\end{array}$ & R/CRA & 55 & $M$ & Late & None & Live \\
\hline
\end{tabular}

Abbreviations: IR/EEA, ileal resection with end-to-end anastomosis; LHC/CSA, left hemicolectomy with colosigmoid anastomosis; LR/EEA, limited resection with end-to-end anastomosis; R/CRA, resection with colorectal anastomosis; RHC/ITA, right hemicolectomy with ileo-transverse colon anastomosis. 
for clean cases, or in cases with satisfied recovery, which we define as early reversal. In case of doubt, we reverse the loop at 2 weeks as a late reversal.

The problem we face after a week is adhesions during reversal of the loop, but it is manageable, and none require laparotomy. In a 70-year-old male patient with superior mesenteric venous occlusion, using ileal resection with ileoileal anastomosis, we reversed the loop by sixth postoperative day, but he developed anastomotic leak on the eighth postoperative day. His fecal fistula was controlled, but he still died, due to the comorbid conditions such as pulmonary tuberculosis and cachexia.

Among the nine cases of early reversal around the seventh day, we faced a leak in one case only, and no complications occurred in six cases who underwent late reversal of loop.

\section{Discussion}

As per Robertson et al, wound infection is the commonly reported complication due to fecal contamination, which is not a problem with our technique, unless we open the bowel. Ileostomy or stoma-related complications and morbidity associated with ileostomy are frequent problems, but they are avoided with covering loop without ostomy. ${ }^{4}$

Chun et al reported problems like readmission for rehydration, midline laparotomy for ileostomy closure, relaparotomy for ileostomy-related complications, and nonclosure of ileostomy. ${ }^{5}$ The above morbidities are not seen in our series of patients.

Stoma creation through laparoscopy is a well-accepted procedure. ${ }^{6}$ Covering loop is also an easy procedure following laparoscopic anastomosis without laparotomy with the help of a loop of the feeding tube, as described already.

Covering loop looks similar to ghost ileostomy, where the bowel is not exteriorized. ${ }^{7-9}$ We exteriorize the ileal loop outside during primary surgery itself to avoid the difficulty in pulling the loop due to postoperative adhesions, which may cause bowel injury. Ghost ileostomy might be suitable for laparoscopic cases, where the chance of postoperative bowel adhesions might be less.

Although, conceptually, covering loop without ostomy and ghost ileostomy are identical in the sense that both are aimed at preventing/reducing the morbidity associated with standard ileostomy, technically, they are different procedures. In covering loop without ostomy, we do covering loop during primary surgery itself, whereas in ghost ileostomy during primary surgery, the loop is identified and hooked with silastic tube, which is kept inside, needing a second surgery to bring out the loop whenever it is necessary. In covering loop without ostomy, when there is no need for ostomy, the loop can be put inside the abdomen using local anesthesia, even by a junior resident, whereas in ghost ileostomy, if at all the loop has to be brought out, it may need the expertise of a consultant.

None of our cases has turned up for follow-up for more than a year, but none developed incision site hernia during follow-up. No peritonitis was observed following loop reversal.

Even though our study took into account only a small sample size, it can be a good technique in terms of morbidity in the emergency setting. It needs further studies to find out the complications like obstruction of the loop, peritonitis following reversal of the loop, incisional hernia, and the authenticity of the technique itself.

\section{Conclusion}

Covering ileal loop is simple modification of loop ileostomy and ghost ileostomy, which can reduce complications related to stoma, patient morbidity, and time duration of the surgery.

\section{Conflict of Interest}

None declared.

\section{References}

1 Abegg RM, Brokelman W, van Bebber IP, Bosscha K, Prins HA, Lips DJ. Results of construction of protective loop ileostomies and reversal surgery for colorectal surgery. Eur Surg Res 2014;52(1-2):63-72

2 Amin SN, Memon MA, Armitage NC, Scholefield JH. Defunctioning loop ileostomy and stapled side-to-side closure has low morbidity. Ann R Coll Surg Engl 2001;83(4):246-249

3 Chen F, Stuart M. The morbidity of defunctioning stomata. Aust N Z J Surg 1996;66(4):218-221

4 Robertson JP, Puckett J, Vather R, Jaung R, Bissett I. Early closure of temporary loop ileostomies: a systematic review. Ostomy Wound Manage 2015;61(5):50-57

5 Chun LJ, Haigh PI, Tam MS, Abbas MA. Defunctioning loop ileostomy for pelvic anastomoses: predictors of morbidity and nonclosure. Dis Colon Rectum 2012;55(2):167-174

6 Oliveira L, Reissman P, Nogueras J, Wexner SD. Laparoscopic creation of stomas. Surg Endosc 1997;11(1):19-23

7 Miccini M, Amore Bonapasta S, Gregori M, Barillari P, Tocchi A. Ghost ileostomy: real and potential advantages. Am J Surg 2010;200(4):e55-e57

8 Cerroni M, Cirocchi R, Morelli U, et al. Ghost ileostomy with or without abdominal parietal split. World J Surg Oncol 2011;9:92

9 Mori L, Vita M, Razzetta F, Meinero P, D’Ambrosio G. Ghost ileostomy in anterior resection for rectal carcinoma: is it worthwhile? Dis Colon Rectum 2013;56(1):29-34 